MARIAN MIKOŁAJCZYK

Uniwersytet Ślaski w Katowicach

\title{
SADOWNICTWO W MIASTACH PRYWATNYCH W POLSCE XVI-XVIII WIEKU. PROBLEM ODRĘBNOŚCI POSTĘPOWANIA W SPRAWACH KRYMINALNYCH
}

Zarys treści: W artykule przedstawiono odmienności ustrojowo-prawne miast prywatnych. Przede wszystkim wskazano różnice w postępowaniu karnym w miastach królewskich i prywatnych oraz starano się ustalić, czy różnice te były na tyle istotne, by pozwoliły uznać proces karny w miastach prywatnych za odrębny tryb postępowania sądowego. W pierwszym typie ośrodków miały miejsce interwencje starostów i innych podmiotów ,zewnętrznych” w miejski wymiar sprawiedliwości. Charakterystyczny dla miast prywatnych był zaś wpływ właścicieli na kształt sądownictwa miejskiego i ich udział w kolejnych etapach postępowania kryminalnego. W artykule omówiono również zakres ingerencji właścicieli w funkcjonowanie miejskiego wymiaru sprawiedliwości.

The content outline: The paper presents the systemic and legal disparities of private towns. Most emphasis is placed on the differences of criminal proceedings in royal and private townsand on determining whether these disparities were significant enough for the criminal process in private towns to be considered a separate manner of criminal proceeding. In case of the former, the municipal judiciary was often subject to interventions from starosts or other "third-party" entities. A characteristic feature of the legal system of private towns, on the other hand, was the influence of their owners on the municipal judiciary and their participation in each stage of criminal proceedings. The paper also discusses the extent to which the owners interfered with the operation of the municipal legal system.

Słowa kluczowe: prawo miejskie, miasta prywatne, proces karny

Keywords: municipal law, private towns, criminal proceedings

W badaniach prowadzonych nad dziejami miast i mieszczaństwa w przedrozbiorowej Rzeczypospolitej na ogół postrzegamy miasta prywatne (szlacheckie i duchowne) jako odrębną kategorię osad miejskich, 
zdecydowanie różniąca się od miast królewskich pod względem ustrojowo-prawnym, mimo że formalnie i jedne, i drugie lokowane były na tym samym prawie magdeburskim bądź jego chełmińskiej odmianie, i że zarówno w jednych, jak i w drugich na owo „prawo majdeburskie" chętnie się powoływano, zwłaszcza w orzeczeniach sądowych. Odmienny charakter miast prywatnych, rzucający się w oczy zwłaszcza w epoce wczesnonowożytnej, przejawiał się przede wszystkim w najrozmaitszych formach ingerencji pana i jego urzędników w życie miasta, przy czym mamy tu na myśli nie tylko doraźne interwencje, ale także - może nawet przede wszystkim - tworzenie ram prawnych, w których funkcjonować winno miasto, jego władze i mieszkańcy. Zawarte w ordynacjach pańskich i innych aktach prawnych przepisy określały zasady powoływania władz miejskich, precyzowały kompetencje poszczególnych organów, nakładały na owe organy konkretne obowiązki. Określano w nich obowiązki mieszczan wobec właściciela i miasta, regulowano funkcjonowanie cechów, starano się zabezpieczyć miasto przed pożarami, zapewnić przestrzeganie dobrych obyczajów itp. ${ }^{1}$ Wiemy też, że sprawowany nad miastem nadzór rozciagał się również na szeroko rozumianą sferę wymiaru sprawiedliwości. Właściciele miast zapewniali sobie znaczący wpływ na obsadę sprawujących sądy urzędów miejskich, we wspomnianych ordynacjach wśród norm mających zapewnić porządek, spokój i ład obyczajowy odnajdujemy też przepisy karne ${ }^{2}$,

${ }^{1}$ Por. np. M. Bogucka, w: M. Bogucka, H. Samsonowicz, Dzieje miast i mieszczaństwa $w$ Polsce przedrozbiorowej, Wrocław 1986, s. 393-396, 401-402; D. Mazek, Ku ozdobie i profitowi. Prawodawstwo miast prywatnych Wielkopolski 1660-1764, Warszawa 2003, s. 78-162, passim; W. Witkowski, Ordynacje pańskie dla miast prywatnych w Polsce XVII i XVIII stulecia, w: Z historii państwa, prawa, miast i Polonii. Prace ofiarowane profesorowi Władysławowi Ćwikowi w czterdziestolecie jego pracy twórczej, red. J. Ciagwa, T. Opas, Rzeszów 1998, s. 454-464; M. Zajęcki, Instrumenty prawne ochrony przeciwpożarowej w miastach Polski przedrozbiorowej, Poznań 2014, s. 72-79. Warto dodać, że rozwiązania prawnoustrojowe występujące w niektórych miastach prywatnych bardzo daleko odbiegały od typowej struktury władz miejskich. Można wspomnieć o przepisach wydanych przez Annę Jabłonowska, która w swych miastach stworzyła specyficzne struktury organów jednoosobowych w postaci komendanta miasta, landwójta, burmistrzów będacych jego zastępcami, wreszcie wspierajacych ich ławników. W Łasku wójt był najwyraźniej utożsamiany z burmistrzem; W. Witkowski, dz. cyt., s. 460-462. Franciszek Leśniak przypuszcza z kolei, że w Limanowej władzę sprawował wójt i ława sądowa, natomiast rada miejska poza pewnymi okresami mogła nawet nie istnieć, a w każdym razie jej znaczenie w życiu miasta było minimalne; tenże, Miasto $w$ latach 1565-1772, w: Limanowa. Dzieje miasta, t. 1: 1565-1945, red. F. Kiryk, Kraków 1999, s. 87-91.

${ }^{2}$ Zob. np. Z. Kulejewska-Topolska, Nowe lokacje miejskie $w$ Wielkopolsce od XVI do końca XVIII wieku. Studium historyczno-prawne, Poznań 1964, s. 114-116; D. Mazek, 
udział władz dominialnych zaznaczał się także w szczególnie nas interesującym postępowaniu sądowym w sprawach kryminalnych.

Samo jednak stwierdzenie angażowania się pana i jego urzędników $\mathrm{w}$ procedowanie $\mathrm{w}$ sprawach karnych $\mathrm{z}$ pewnościa nas nie zadowala. Należałoby bowiem postawić w tym wypadku dwa zasadnicze pytania: Jakie odrębności wykazywało postępowanie sądowe w sprawach kryminalnych $\mathrm{w}$ miastach prywatnych $\mathrm{w}$ porównaniu z procedurami w miastach królewskich? Jeżeli zaś takie odmienności istniały, to czy były one na tyle istotne i powszechne, by można było mówić o specyfice procesu w owych miejscowościach?

Odpowiedź na pierwsze pytanie częściowo znamy, dotychczasowe badania praktyki pozwoliły bowiem dostrzec niektóre, gdzie indziej niewystępujace zjawiska, a zwłaszcza znaczący udział w postępowaniu podmiotów spoza miasta: właściciela i innych przedstawicieli władz dominialnych. Nie oznacza to jednak, że charakterystyczne dla miast prywatnych czynności lub instytucje procesowe nie miały żadnych odpowiedników w innych miastach, o czym będzie jeszcze mowa. Ponadto owe odmienności jawią się nam jednak w postaci albo pojedynczych przykładów podawanych przy okazji rozważania innych problemów, albo też zwrócenia uwagi na wybraną instytucję czy też czynność procesowa - i to zazwyczaj w ramach obserwacji odnoszących się do konkretnego miasta ${ }^{3}$. Brakuje natomiast próby bardziej ogólnego, całościowego ujęcia problemu, dlatego też wskazane wydaje się przypomnienie i pewne uporządkowanie naszej wiedzy.

Właściciele niewątpliwie mogli wywierać wpływ na organizację wymiaru sprawiedliwości w mieście, czy wręcz ją kształtować, np. roz-

dz. cyt., s. 150-154; J. Mazurkiewicz, Jurydyki lubelskie, Wrocław 1956, s. 70-73; tenże, $O$ niektórych problemach prawno-ustrojowych miast prywatnych $w$ dawnej Polsce, „Annales Universitatis Mariae Curie-Skłodowska” 1964, Sectio G, t. 11, z. 4, s. 115-117; J. Mazurkiewicz, J. Reder, J. Markiewicz, Miasta prywatne powiatu lubelskiego a ich dziedzice w XIX w. (Do ukazów uwłaszczeniowych), „Annales Universitatis Mariae Curie-Skłodowska” 1954, Sectio G, t. 1, z. 3, s. 119-120.

${ }^{3}$ Tak M. Mikołajczyk, O zatwierdzaniu wyroków sqdu miejskiego w Nowej Górze w XVIII wieku, w: Studia z dziejów państwa i prawa polskiego, t. 5, red. J. Matuszewski, W. Uruszczak, Łódź-Kraków 2000; tenże, Proces kryminalny w Nowej Górze XVI-XVIII wieku, w: Miscellanea Iuridica, t. 7: Między I a III Rzeczapospolita. Ksztattowanie europejskiej kultury prawnej. Prace ofiarowane prof. zw. dr. hab. Adamowi Lityńskiemu w czterdziestolecie pracy naukowej, red. M. Mikołajczyk, A. Drogoń, Tychy 2005; tenże, Nadzór właścicieli wielkopolskiego Grodziska nad miejskim sqdownictwem $w$ sprawach kryminalnych $w$ I połowie XVIII wieku, w: Historia testis temporum, lux veritatis, vita memoriae, nuntia vetustatis. Ksiega jubileuszowa dedykowana profesorowi Włodzimierzowi Kaczorowskiemu, red. E. Kozerska, M. Maciejewski, P. Stec, Opole 2015. 
graniczając kompetencje organów miejskich ${ }^{4}$ albo też zakreślając ich właściwość ${ }^{5}$ (m.in. nakładając obowiązek sądzenia spraw kryminalnych poddanych z dóbr pańskich ${ }^{6}$ ). Znane są też upomnienia kierowane

${ }^{4}$ Przypomnijmy choćby przywilej dla Łobżenicy, przewidujący - wbrew rozpowszechnionej $\mathrm{w}$ małych miastach praktyce wymierzania sprawiedliwości przez złożony sad radziecko-ławniczy - powierzenie spraw sądowych jedynie wójtowi i ławnikom, co miało przywracać tradycyjny, zgodny z prawem magdeburskim podział kompetencji między radę i ławę. Utrzymano jednak pewien wyjątek. W najpoważniejszych sprawach karnych, „gdzie o honor albo krew ludzką idzie, [...] ażeby się nic nie ubliżyło sprawiedliwości i niewinności ludzkiej”, wójt miał „urzędu burmistrzowskiego na takową sprawę do spólnej rady wzywać”. Sąd taki zwać się miał „iudicium compositum sententiae”; Przywilej miastu Łobżenice nadany przez Jana Korzboka Eqckiego, Poznań 1883, s. 43, ks. 1, art. 9. Wspomina o tym postanowieniu (jednak bez szczegółów) D. Mazek, dz. cyt., s. 119 (tam też inne przykłady); zob. też Z. Kulejewska-Topolska, dz. cyt., s. 104-105, 99-100. Z kolei Andrzej Firlej, wydając w 1580 r. przywilej dla Janowca nad Wisła, utwierdzał zasadę wspólnego sprawowania sądów przez radę i ławę, nakazując, by „na każde dwie niedzieli, okrom we żniwa, w jeden piątek od południa, wójt $\mathrm{z}$ ławniki w ratuszu u jednego stołu, a burmistrz z rajcami tamże u drugiego stołu [...] siadać i sprawiedliwość czynić każdemu kto jej z kogo żądać u nich będzie, nieodwłocznie powinni”; A. Wyrobisz, Poczatki miasta Janowca nad Wista. Dokumenty $z$ lat 1537, 1566, 1580, [Janowiec nad Wisła] 1999, s. 50 (nr 3). O sposobie zasiadania sądów opatowskich określonym przez właścicieli miasta zob. M.T. Trojan, Dzieje sqdownictwa wielkiego Opatowa, Sandomierz 1938 , s. 42.

${ }^{5}$ Stosunkowo dobrze rozpoznana jest właściwość sądów miast prywatnych w sprawach Żydów. W tym wypadku szczególnie wyraźnie widać rolę właścicieli miast, którzy albo pozostawiali owe sprawy sądom miejskim, albo zastrzegali je do właściwości sądów dominialnych; por. A. Kaźmierczyk, Żydzi $w$ dobrach prywatnych $w$ świetle sqdowniczej $i$ administracyjnej praktyki dóbr magnackich $w$ wiekach XVI-XVIII, Kraków 2002, s. 27-40, 107-118, 130-131, 176-185, 213-216, passim; Z. Kulejewska-Topolska, dz. cyt., s. 113-114; A. Zajac, Управління та саловрядування в містах Правобережної України у XVI - першій половині XVII cm. за данили локаиійних привілеїв та документів, w: Urzędy państwowe, organy samorzqdowe $i$ kościelne oraz ich kancelarie na polsko-ruskim pograniczu kulturowym $i$ etnicznym $w$ okresie od XV do XIX wieku. Materiaty polsko-ukrainskiej konferencji naukowej w Okunince koło Włodawy, 10-12 września 2007 roku, red. H. Gmiterek, J. Łosowski, Kraków 2010, s. 235-236; zob. też M. Mikołajczyk, Proces kryminalny w miastach Małopolski XVI-XVIII wieku, Katowice 2013, s. 78.

${ }^{6}$ Wspomnijmy tu ordynację z 1580 r. dla Janowca, zgodnie z którą miasto miało obowiązek sądzić każdego „złoczyńcę” oddanego przez pana (,winien go urząd miejski do kaźni swej przyjąć i więzieniem jakoby nie uciekł opatrzyć pod winą 20 grzywien pieniędzy, po kata posłać [...] i z niego wedle jego zasługi sprawiedliwość uczynić”), przy czym koszty postępowania ponosić miał właściciel miasta; A. Wyrobisz, dz. cyt., s. 49; por. także uwagi (niezbyt precyzyjne) G. Janusza, Miasto Janowiec nad Wista. Ustrój władz miejskich i stosunki społeczno-ekonomiczne w świetle przywilejów, Janowiec 1999, s. 40; zob. też M. Mikołajczyk, Proces kryminalny w miastach..., s. 69. 
pod adresem sędziów, by rozpoznawali sprawy sprawiedliwie, a także na trzeźwo (nie po pijanemu $)^{7}$.

Nakładane na miasto i mieszczan obowiązki w zakresie zapewnienia bezpieczeństwa, utrzymania porządku i obyczajności w niektórych przypadkach mogły się stać elementem postępowania karnego, przybrać postać nieformalnego śledztwa czy też udziału w ściganiu złoczyńców. Można tu podać przykład z Żywca, którego mieszkańcom w 1633 r. nakazano, by w razie napadu zbójców „za najmniejszym rozkazaniem starosty naszego [...] i zniesieniem się osobnym z urzędem radzieckim” stawili się ,jak na ogień” z bronią i na owych zbójców uderzali ${ }^{8}$, a także przytoczyć przepisy ordynacji nakładajacych na władze miejskie wyłapywanie ludzi luźnych, nierządnych kobiet itp. ${ }^{9}$

W pewnym stopniu praktyczną realizacja nakładanego na władze miejskie obowiazku rozpatrywania spraw kryminalnych poddanych pana miasta było wszczynanie postępowania „z woli i rozkazu” właściciela $^{10}$ albo też osób działających w jego zastępstwie ${ }^{11}$, co - przynajmniej

7 T. Maciejewski, Narzędzia tortur, sqdów bożych i prób czarownic, Koszalin 1997, s. 27; M.T. Trojan, dz. cyt., s. 43.

${ }^{8}$ Materiaty do dziejów miasta Żywca od XV do XVIII wieku, wyd. F. Lenczowski, Kraków 1957, s. 109-110 (nr 14); A. Komoniecki, Chronografia albo Dziejopis żywiecki, wyd. S. Grodziski, I. Dwornicka, Żywiec 1987, s. 148.

9 Por.: „XI. Ludzie luźni aby w mieście nie byli, którzy by się znaleźli, ma być okowan i do zamku podan. XII. Nierządnic aby żaden mieszczanin nie przechował w domu pod kopą winy. XIII. Kartowników, oszustów, kosterców mieszczanie w domach swych nie maja przechowywać"; Uchwała albo porzqdek postanowienia artykutów, wedle których opisania mieszczanie i obywatele miasta Liska sprawować się i obchodzić maja [1602 r.], w: A. Fastnacht, Dzieje Leska do 1772 roku, Rzeszów 1988, s. 325; „Rozkaz burmistrzowi łańcutckiemu, ażeby dla wyjścia obrazy Boskiej uczynił w całym mieście rewizja, jeżeli jakich białychgłów swywolnych rozposto [rozpusta - M.M.] się znajdowały bawiących się w mieście, które żeby zaraz, jeżeliby się znajdowały, taki z miasta relegował bez żadnego respektu na nikogo"; Kopiariusz przywilejów miasta Łańcuta, wyd. M. Nitkiewicz, Łańcut 1986, s. 23 (1727 r.); zob. też D. Mazek, dz. cyt., s. 104-105, 147-154.

10 Zob. np. AGAD, Biblioteka Baworowskich (dalej. BBaw.), sygn. 252 (Grodzisk Wielkopolski), k. 5 v (1704-1706), 30v (1713 r.), 39 (1714 r.), 41 (1714 r.), 49v (1715 r.), 56 (1719 r.), 61 (1722 r.), 62v (1725 r.); AP w Krakowie, Inwentarz tymczasowy (dalej: IT), sygn. 229g (Nowa Góra), s. 41 (1694 r.).

${ }_{11}$ AGAD, BBaw., sygn. 252 (Grodzisk Wielkopolski), k. 6v (1706 r. - ekonom właściciela Grodziska); AP w Krakowie, IT, sygn. 229b (Nowa Góra), s. 33 (1680 r. - dzierżawca wsi Krzeszowice, wchodzącej w skład dóbr tęczyńskich, do których należało miasto), 114 (1686 r. - dzierżawca klucza tęczyńskiego); tamże, sygn. 229h (Nowa Góra), s. 17 (1752 r. - komisarz dóbr); BJ, sygn. 86, k. 96v (1746 r. - komisarz-administrator dóbr); Muzeum Okręgowe w Tarnowie, sygn. MT-H 505 (Tarnów), k. 35-35v (1757 r. - ekonom hrabstwa tarnowskiego) i być może też k. 50-50v (1761 r.), 68v-69 (1765 r.), 
w niektórych przypadkach - nie musiało stanowić zaprzeczenia zasady skargowości ${ }^{12}$. Polecenie rozpoznania sprawy mogło być zresztą konsekwencja skargi, skierowanej jednak nie wprost do sądu miejskiego, lecz do władz dominialnych (zamku). Z taką praktyką spotykamy się np. w Rzeszowie ${ }^{13}$ czy też XVIII-wiecznym Tarnowie ${ }^{14}$.

Być może nie była to jedyna forma angażowania się władz dominialnych na etapie wszczęcia postępowania, znamy bowiem przypadek sprowadzenia sądu z należącego do klasztoru Bożogrobców Miechowa do pobliskiej wsi na prośbę jej dzierżawcy „za wiadomością JM Pana Stefana Opatkowskiego, starosty miechowskiego" ${ }^{15}$. Być może więc przynajmniej w niektórych miastach - skorzystanie z usług sądu miejskiego wymagało zgody właściciela miasta bądź jego urzędników.

Przedstawiciele władz dominialnych uczestniczyli też $\mathrm{w}$ postępowaniu sądowym. W aktach nieraz zaznaczano, że proces toczył się w obecności (in praesentia) dzierżawcy lub administratora dóbr, starosty, podstarościego itp. ${ }^{16}$ Niekiedy dodawano zreszta, że reprezentowali

81v (1766 r.), gdzie mowa o decyzjach zwierzchności zamkowej; AP w Krakowie, IT, sygn. 229g (Nowa Góra), s. 96-97 (1701 r. - burgrabia zamku tęczyńskiego); Archiv Jugo-Zapadnoj Rossji, t. 5, cz. 1, Kijew 1869, s. 267 (nr CVIII, Dubno, 1716 r. - tu wszczęcie „za rozkazaniem zwierzchności zamkowej”).

${ }_{12} \mathrm{Na}$ przykład w 1694 r. sąd nowogórski rozpoznawał sprawę „z wolej i rozkazania” pana miasta, ale na podstawie skargi burgrabiego zamku tęczyńskiego; AP w Krakowie, IT, sygn. 229g, s. 41-42; szerzej na ten temat zob. M. Mikołajczyk, Proces kryminalny $w$ miastach..., s. 187-188.

13 J. Pęckowski, Dzieje miasta Rzeszowa do końca XVIII wieku, Rzeszów 1913 (reprint: Krosno 2002), s. 177.

${ }^{14}$ W 1765 r. proces z oskarżenia wójta lisiogórskiego toczył się „przy wyraźnej dyspozycyi zwierzchności zamkowej”; Muzeum Okręgowe w Tarnowie, sygn. MT-H 505, k. 76. Niewykluczone, że podobny tryb wszczęcia postępowania miał miejsce w innych sprawach rozpatrywanych przez sąd tarnowski na podstawie decyzji „zwierzchności zamkowej”; Muzeum Okręgowe w Tarnowie, sygn. MT-H 505, k. 35-35v (1757 r. oskarżycielem był pokrzywdzony Haskiel Karczmarz), 50-50v, 52v (1761 r. - w roli oskarżyciela występowały gromady wiejskie, a później instygator), 68v-69 (1765 r. - oskarżali wójt i przysiężnik wsi, z której pochodzili oskarżeni), 81v (1766 r. - oskarżycielami byli przedstawiciele gromady Wierzchosławice i instygator miejski).

${ }^{15}$ BJ, sygn. 86 (Miechów), k. 74v (1677 r.).

${ }_{16}$ Tak w Miechowie, gdzie odnotowywano obecność różnych przedstawicieli klasztoru Bożogrobców (właściciela miasta) - starosty, podstarościego, wiceprefekta konwentu; tamże, k. 60 (1640 r.), 63v (1652 r.), 66 (1656 r.), 69 (1661 r.). Podobnie w Nowej Górze; AP w Krakowie, IT, sygn. 229b, s. 158-160 (1688 r.); BJ, sygn. 122, k. 10 (1749 r.); a także w wielkopolskim Grodzisku; AGAD, BBaw., sygn. 252, k. 30-31v (1713 r.), 34v (1714 r.), 41-42v (1714 r.). Z pewnością trudno byłoby tu dopatrywać się ścisłych reguł. Oto w 1698 r. w Nowej Górze, sporządzając protokół z czynności sądowych, zaznaczono, że wszystko to „się działo i przy Jegomości Panu Szymkiewiczu, synu dzierżawcze samego"; AP w Krakowie, IT, sygn. 229g, s. 70. 
oni w sądzie swoich zwierzchników ${ }^{17}$. Można się zastanawiać, czy ta obecność oznaczała jedynie bierne przypatrywanie się poszczególnym czynnościom, kontrolowanie poczynań sądu i ewentualne informowanie właścicieli o dostrzeżonych nieprawidłowościach. Nie można bowiem wykluczać, że formularzowy zwrot mówiący o obecności urzędników oznaczał $\mathrm{w}$ istocie uczestniczenie $\mathrm{w}$ postępowaniu w czynny sposób ${ }^{18}$. W niektórych przypadkach zapiski nie pozostawiają zresztą większych wątpliwości, wynika z nich bowiem, że osoby reprezentujące władze dominialne stawały się członkami składu orzekającego, a nawet obejmowały jego przewodnictwo ${ }^{19}$.

Znamy też sporadyczne przypadki przejmowania przez właściciela miasta lub przedstawiciela władz dominialnych sprawy karnej do osobistego jej rozpatrzenia. Tak postapiono w 1698 r. w Nowej Górze, kiedy to sąd miejski odesłał sprawę Błażeja Klepki, oskarżonego o cudzołóstwo, do pana miasta, który „respektem usług jego i koło galmanu robienia zniewolony", darował mu karę śmierci. Sąd miejski potwierdził ów „dekret ferowany od Jaśnie Wielmożnego Pana Jegomości Dobrodzieja" i skazał oskarżonego na chłostę oraz oddanie wosku do kościoła ${ }^{20}$. W tym wypadku miało zapewne miejsce swego rodzaju

${ }^{17} \mathrm{Na}$ przykład w 1714 r. postępowanie przed sadem grodziskim toczyło się „in praesentia generosi Alexandri Ermanowski ab Illustri Magnifico Joanne de Bnin Opaliński, capitaneo sremensi, Haeredi Civitati Grodzisci deputati”; AGAD, BBaw., sygn. 252, k. 34v. W Nowej Górze w 1749 r. sprawa była rozpatrywana „przy prezencyi Jegomości Pana Jacka Wójtowskiego, administratora grójeckiego, od [...] ekonoma hrabstwa tęczyńskiego deputowanego"; BJ, sygn. 122, k. 10.

${ }_{18}$ Możemy zresztą przypuszczać, że obecność reprezentantów pana miasta zmuszała sędziów do szczególnie starannego prowadzenia postępowania; por. M. Mikołajczyk, Nadzór właścicieli..., s. 388-389.

${ }^{19}$ Na przykład w Miechowie w 1580 r. wspomniano, że obwiniony złożył zeznania „przed Jegomością starostą miechowskim, przed panem wójtem i pany burmistrzem i radą miechowską"; BJ, sygn. 86, k. 20. W Nowej Górze w 1679 r. zaznaczono, że zarówno postanowienie odsyłające oskarżonego na tortury, jak i końcowy dekret zostały wydane przez „urząd miasteczka Nowej Góry spólnie z Jegomością Panem Marcjanem Kozłowskim, podstarościm tęczyńskim”; AP w Krakowie, IT, sygn. 229b, k. 20-21. Również w księdze spraw kryminalnych z Grodziska Wielkopolskiego w kilku przypadkach zapisano, że postępowanie toczyło się nie tylko przed władzami miejskimi, ale i przed dzierżawcą bądź oddelegowanym w tym celu przez właściciela miasta ekonomem; AGAD, BBaw., sygn. 252, k. 46 (1715 r.), 51-51v (1716 r.), 93v, 96v-97 (1738 r.); zob. też M. Mikołajczyk, Nadzór właścicieli..., s. 389-390. O przewodniczeniu sądom miejskim przez gubernatora opatowskiego wspomina (dość niejasno) M.T. Trojan, dz. cyt., s. 25.

${ }^{20}$ AP w Krakowie, IT, sygn. 229g, s. 68. Niewykluczone, że również znacznie wcześniej, bo w 1586 r. nowogórskie władze miejski przeprowadziły tylko skrutynium, końcowy wyrok wydał zaś starosta zamku tęczyńskiego; tamże, sygn. 229c, s. 28-30. 
współdziałanie sądu miejskiego i władz dominialnych ${ }^{21}$. Natomiast w 1714 r. w Grodzisku Wielkopolskim Jan z Bnina Opaliński niewatpliwie sam skazał Żyda Abrahama Kuśnierza, który dał był „dwa razy w gębę" tamtejszemu mieszczaninowi, dodając przy tym prejudykat grożący grodziskim Żydom surowymi karami za podobne uczynki i nakazujący tymże Żydom i chrześcijanom powstrzymywanie się od zachowań, które mogłyby stać się przyczyną konfliktu ${ }^{22}$.

Trochę inną kategorię stanowiły spory, w których wydanie orzeczenia przez władze dominialne uzasadnione było szczególnymi okolicznościami. W 1688 r. we wspomnianej Nowej Górze dzierżawca klucza tęczyńskiego, do którego należało miasteczko, uczestniczył w rozprawie przeciwko oskarżonym, którym zarzucano swary, hałasy i najście na dom burmistrza, a potem sam, chcąc zapobiec podobnym ekscesom w przyszłości, wydał wyrok na swawolników i przy okazji nałożył dość surowe kary na burmistrza i wójta za to, że do owych awantur dopuścili²3. W 1723 r., w tymże miasteczku „deputowani od zamku tęczyńskiego” uznali, że władze miejskie, nie zachowawszy należytej staranności, przyczyniły się do śmierci osadzonego w więzieniu aresztanta, i nałożyli na pisarza miejskiego karę 100 grzywien na rzecz zamku i Kościoła ${ }^{24}$. W obu przypadkach zdyscyplinować należało członków władz miasta - nie dziwi zatem tak daleko idące zaangażowanie zwierzchników ${ }^{25}$. Jak wiadomo, pewien wpływ na ostateczny kształt orzeczeń, zwłaszcza ferowanych w małych miastach, miały zanoszone do sądu „instancyje”, czyli wstawiennictwa wpływowych osób. Niekiedy z prośbami

${ }^{21}$ Ostateczne kary orzekł sąd miejski. Nie można też wykluczyć, że już wcześniej, przed odesłaniem sprawy do właściciela, władze miejskie wydały w tej sprawie jakiśs wyrok. W końcowym orzeczeniu dodano bowiem: „A jeśliby, czego Boże zachowaj, ten występek miał [się] być ponowić, my tedy potwierdzamy zwierzchnością nasza, aby według dekretu naszego pierwszego mieczem katowskim byli karani”; tamże, sygn. 229g, s. 68; zob. też M. Mikołajczyk, Proces kryminalny w Nowej Górze..., s. 215.

${ }^{22}$ Wyrok „Jaśnie Wielmożnego Pana Jana z Bnina Opalińskiego, starosty śremskiego, dziedzica miasta tego, Pana i Dobrodzieja Naszego, jako Supremi Arbitri et Iudicis” stwierdzał, że skoro „Żyd nie ma czym płacić [...] tedy redimendo caput ipsius, należało było, aby mu rękę ucięto, lecz nagorące instancje godnych osób” wniesione do pana miasta ostatecznie darowano mu tę karę. Żyd Kuśnierz winien być zatem „z miasta [...] relegowany”, a wcześniej powinien przeprosić pokrzywdzonego „na miejscu tym, gdzie bił"; AGAD, BBaw., sygn. 252, k. 40-41.

${ }^{23}$ AP w Krakowie, IT, sygn. 229b, s. 158-160; M. Mikołajczyk, Proces kryminalny $w$ Nowej Górze..., s. 215-216.

${ }^{24}$ BJ, sygn. 122, k. 9; M. Mikołajczyk, Proces kryminalny w Nowej Górze..., s. 216.

25 Por. spostrzeżenia J. Mazurkiewicza odnoszące się do jurydyk lubelskich. Tu również sprawy, w których stroną byli urzędnicy należały do sądu pańskiego; tenże, Jurydyki..., s. 73. 
takimi występowano jeszcze przed wydaniem wyroku ${ }^{26}$, przy czym znamy przypadki ( $\mathrm{z}$ wielkopolskiego Grodziska ${ }^{27}$ ), kiedy to kierowano je nie do sądu rozpatrującego sprawę, lecz do pana miasta. Z użytych $\mathrm{w}$ wyrokach sformułowań wynikałoby, że w takiej sytuacji właściciel wspólnie z sądem miejskim ustalał treść wyroku, choć możemy przypuszczać, że głos decydujący należał do pana miasta ${ }^{28}$.

Pan miasta dla swych poddanych (chłopów i mieszczan) stanowił najwyższą instancję sądowa. Odwołania od wyroków sądów miejskich do sądu pańskiego lub innych sądów dominialnych miały miejsce także w sprawach kryminalnych, choć były to przypadki stosunkowo nieliczne ${ }^{29}$. Jest to zreszta zrozumiałe - dopuszczalność apelacji $\mathrm{w}$ tego typu sprawach była kwestią dyskusyjną i sądy I instancji przyjmowały ją tylko wyjątkowo ${ }^{30}$. Ponadto $\mathrm{w}$ miastach prywatnych istniały jeszcze inne możliwości kontroli orzeczeń.

Bodaj najczęściej występująca formą pańskich interwencji w miejski wymiar sprawiedliwości było zatwierdzanie (albo zmienianie) orzeczeń wydawanych przez sądy, chociaż i w tym wypadku praktyka prawdopodobnie była daleka od jednolitości. W niektórych miastach właściciele w wydawanych przez siebie ordynacjach wyraźnie zastrzegali sobie lub swoim urzędnikom prawo aprobowania zapadłych w mieście orzeczeń w sprawach kryminalnych. Takie postanowienia znamy z Ostrowa Wielkopolskiego ${ }^{31}$, Białegostoku ${ }^{32}$, można też przytoczyć ustawę dla

${ }^{26}$ M. Mikołajczyk, Proces kryminalny $w$ miastach..., s. 455.

${ }^{27}$ Niewykluczone, że z podobnym sposobem postępowania mamy do czynienia w Kołaczycach w 1638 r. Jest bowiem możliwe, że opat komendatoryjny tyniecki Karol Ferdynand Waza, jako pan miasta, jeszcze przed wydaniem wyroku poinformował sędziów miejskich, jaką karę śmierci orzec należy wobec winowajczyni, a nawet, w jaki sposób mają ferować wyrok - grożąc karami w razie niezastosowania się do poleceń; W. Sarna, Opis powiatu jasielskiego, Jasło 1908 (reprint: Jasło 2003), s. 551-552.

${ }^{28}$ M. Mikołajczyk, Nadzór właścicieli..., s. 392-393.

${ }^{29} \mathrm{Na}$ przykład Muzeum Okręgowe w Tarnowie, sygn. MT-H 505 (Tarnów), k. 66-66v (1763 r.); BJ, sygn. 86 (Miechów), k. 51 (1628 r.); por. też przypadek z Żywca z 1662 r.: A. Komoniecki, dz. cyt., s. 206; M. Mikołajczyk, Proces kryminalny w miastach..., s. 517, zob. też s. 513-514 (zwł. przyp. 32).

${ }^{30}$ Por. M. Mikołajczyk, Proces kryminalny $w$ miastach..., s. 509-519. We wzmiankowanej w poprzednim przypisie sprawie z Tarnowa z 1763 r. sąd nie dopuścił do apelacji i dopiero złożony przez skazanego „solenny manifest” i protestacja przeciwko władzom miejskim spowodowały - jak się wydaje - że sprawa trafiła do sądu zamkowego; Muzeum Okręgowe w Tarnowie, sygn. MT-H 505, k. 66-66v.

${ }^{31}$ T. Opas, Zagadnienie apelacji mieszczan miast prywatnych $w$ świetle polityki gospodarczo-społecznej dziedziców od XVI do XVIII wieku, „Annales Universitatis Mariae Curie-Skłodowska" 1973, Sectio G, t. 20, z. 2, s. 29.

32 A. Sztachelska-Kokoczka, A. Oleksicki, Biatystok $w$ czasach Branickich (lata 1708-95), w: Historia Białegostoku, red. A.C. Dobroński, Białystok 2012, s. 104. 
Żywca z 1626 r., chociaż w tym przypadku nałożono na miasto obowiązek informowania starosty nie o karach kryminalnych, lecz pieniężnych, zaznaczając, że tenże starosta ma podejmować ostateczne decyzje co do rodzaju i wysokości owych „win”33.

Również badania praktyki dowodzą sprawowania przez właścicieli niektórych miast $\mathrm{w}$ miarę stałego nadzoru nad orzeczeniami sądów miejskich i to nie tylko kończącymi postępowanie. Stosunkowo dobrze znane nam sa tego typu działania podejmowane w małopolskiej Nowej Górze i wielkopolskim Grodzisku ${ }^{34}$. W obu tych miastach obserwujemy bowiem przedkładanie panu miasta (lub komisarzowi dóbr, ekonomowi, dzierżawcy) wyroków do zatwierdzenia, przy czym w Nowej Górze czyniono to dość systematycznie (nawet w niektórych sprawach cywilnych) ${ }^{35}$. Z tejże Nowej Góry znamy nawet przykład zwrócenia się przez sąd miejski do komisarza dóbr tęczyńskich o zatwierdzenie dekretu zapadłego $\mathrm{w}$ toku postępowania dotyczącego oddania obwinionego na tortury ${ }^{36}$.

Zatwierdzanie wyroków sądów miejskich przez właścicieli lub (najczęściej) pańskich starostów, gubernatorów itp. miało miejsce także $\mathrm{w}$ wielu innych miejscowościach - w Miechowie, Rzeszowie, Tarnowie, Nowym Wiśniczu, Opatowie, Żywcu ${ }^{37}$. W tym wypadku mamy jednak na ogół do czynienia (o ile można wierzyć źródłom) nie tyle ze stała praktyka, ile z działaniami doraźnymi, sporadycznymi. Zreszta nawet we wspomnianych Nowej Górze i Grodzisku zdarzały się wcale liczne sprawy, w których nie odnotowano żadnych form kontroli wyroków przez władze dominialne ${ }^{38}$. Możemy zatem przypuszczać,

${ }^{33}$ A. Komoniecki, dz. cyt., s. 147; Materiaty do dziejów miasta Żywca..., s. 107 (nr 14).

${ }^{34}$ Być może podobnie postępowano w Pabianicach. Według J. Fijałka zatwierdzanie lub łagodzenie wydawanych przez sąd miejski wyroków śmierci należało do kapituły krakowskiej - właściciela miasta; J. Fijałek, J. Koliński, Dzieje miasta w XVII i XVIII wieku, w: Dzieje Pabianic, red. G. Missalowa, Łódź 1968, s. 97.

35 Szerzej na ten temat zob. M. Mikołajczyk, Nadzór właścicieli..., s. 390-395; tenże, O zatwierdzaniu..., s. 161-167; tenże, Proces kryminalny w Nowej Górze..., s. 210-212; zob. też tenże, Proces kryminalny $w$ miastach..., s. 525-528. Nie jesteśmy w stanie stwierdzić, czy takie sformalizowane postępowanie wynikało $\mathrm{z}$ nieznanych nam przepisów zawartych w ordynacji, czy też ukształtowało się ono w drodze zwyczaju.

${ }^{36}$ BJ, sygn. 122, k. 11 (1749 r.); zob. też M. Mikołajczyk, O zatwierdzaniu..., s. 164; tenże, Proces kryminalny w Nowej Górze..., s. 211; tenże, Proces kryminalny w miastach..., s. 527.

${ }^{37}$ Odpowiednie przykłady przytoczono w M. Mikołajczyk, Proces kryminalny w miastach..., s. 524-527; zob. też M.T. Trojan, dz. cyt., s. 25, 47.

${ }_{38}$ Zob. M. Mikołajczyk, Proces kryminalny $w$ miastach..., s. 528; tenże, O zatwierdzaniu..., s. 166; tenże, Nadzór właścicieli..., s. 396-398. 
że intensywność nadzoru nad orzecznictwem miejskim zależała nie tylko od prawnych uregulowań i zwyczajów, ale także od aktywności konkretnego właściciela miasta czy urzędnika. Nie można także wykluczyć, że w wielu miastach sformalizowane działania zastępowano bardziej dyskretnym nadzorem i interweniowano tylko w razie rzeczywistej potrzeby. W małych na ogół miastach prywatnych poważniejsze procesy zdarzały się przecież niezbyt często i trudno sobie wyobrazić, by do pana i jego urzędników nie docierały na bieżąco informacje o ich przebiegu.

Dodajmy, że część interwencji dotyczących wyroków była w jakimś stopniu inspirowana prośbami (instancjami) zanoszonymi za skazanym wprost do pana miasta bądź jego urzędników ${ }^{39}$.

Niewiele potrafimy powiedzieć o angażowaniu się władz dominialnych $\mathrm{w}$ postępowanie wykonawcze. Wiemy jedynie, że choć miasto Żywiec było związane z Oświęcimiem umowa pozwalająca na korzystanie z usług tamtejszego kata, to jednak w 1721 r. „Państwo samo” sprowadziło mistrza z Pszczyny, tłumacząc to tym, że „oświęcimski pijaństwem się zabawia"40. Nie można jednak wykluczyć i innych form udziału właściciela miasta i jego podwładnych w czynnościach wykonawczych, choćby nadzorowania przebiegu egzekucji ${ }^{41}$.

Omówione formy ingerowania pana w miejski wymiar sprawiedliwości nie wykluczają zapewne innych, dorywczych interwencji podejmowanych w konkretnych sprawach. W opisanej przez Jacka Wijaczkę sprawie o czary toczącej się w Młotkowie w 1692 r. przed sądem łobżenickim właściciel miasta nie tylko czuwał nad przebiegiem postępowania, ale też nieustannie wtrącał się w jego przebieg, podejmował decyzje

${ }^{39}$ Por. przykłady z Nowego Wiśnicza: Acta maleficorum Wisniciae (1665-1785). Księa czarna złoczyńców sadu kryminalnego w Wiśniczu (1665-1785), oprac. i wyd. W. Uruszczak, współpr. B. Migda, A. Karabowicz, A. Uruszczak, Kraków 2010, s. 11 (nr 2, 1666 r.), 35 (nr 10, 1689 r.), 41 (nr 12, 1691 r.), 45 (nr 13, 1692 r.); być może także Acta maleficorum Wisniciae (1629-1665). Księga złoczyńców sqdu kryminalnego w Wiśniczu (1629-1665), wyd. W. Uruszczak, współpr. I. Dwornicka, Kraków [2004], s. 166 (nr 34, 1653 r.) i wielkopolskiego Grodziska: AGAD, BBaw., sygn. 252, k. 43v, 46 (1714 r.), 59-59v (1720 r.), być może również k. 51 (1715 r.).

${ }^{40}$ A. Komoniecki, dz. cyt., s. 531. Być może czterej kaci, którzy w 1688 r. przybyli z Cieszyna, by torturować i przeprowadzić egzekucję niejakiego Wojciecha Miczka, też zostali sprowadzeni przez władze dominialne. Andrzej Komoniecki narzekał bowiem na konieczność zapłacenia im wysokiego honorarium, podczas gdy kat oświęcimski zadowoliłby się o wiele niższą zapłata; tamże, s. 243.

${ }^{41}$ Komoniecki wspomina o obecności podstarościego Stanisława Biegańskiego podczas egzekucji kilku rozbójników w 1658 r. (tamże, s. 200), nie wiadomo jednak, czy ów pański urzędnik obserwował tracenie złoczyńców jako przedstawiciel władz czy był tylko jednym ze zgromadzonych widzów. 
co do przeprowadzenia dowodów, wskazywał, jak mają być traktowane oskarżone, zmieniał skład sądu, wreszcie zatwierdził wyrok ${ }^{42}$.

Jak łatwo zauważyć, wszystkie przedstawione odrębności i odmienności proceduralne sprowadzają się do relacji między miejskimi organami wymiaru sprawiedliwości a panem miasta i podległymi mu urzędnikami, dzierżawcami itp. ${ }^{43}$ Dlatego, starając się odpowiedzieć na drugie $\mathrm{z}$ postawionych na wstępie pytań (czy proces karny w miastach prywatnych wykazywał cechy specyficzne, jemu tylko właściwe?), należałoby w pierwszej kolejności rozważyć, czy omówione szczególne elementy postępowania były charakterystyczne wyłącznie dla miast prywatnych, czy też - w zbliżonej postaci - mogły się pojawiać także w innych miejscowościach.

I tak, gdy mówimy o wszczynaniu postępowania karnego na polecenie właściciela miasta, należałoby wspomnieć o zdarzających się przypadkach przekazywania sądom miejskim (także miast królewskich) spraw przez sądy szlacheckie i inne podmioty „zewnętrzne”. W królewskim Kowlu w 1718 r. sprawa - tak jak w miastach prywatnych - toczyła się „z rozkazania zwierzchności zamkowej”44. Pewne podobieństwo $\mathrm{w}$ sposobie postępowania dostrzegamy też $\mathrm{w}$ przypadku rozpatrywania spraw kryminalnych przez sądy miejskie na żądanie właścicieli czy też dzierżawców okolicznych dóbr (choć w tym wypadku brakuje oczywiście elementu władczości) ${ }^{45}$. Można się też zastanawiać, czy cechą wyróżniającą postępowanie karne w miastach prywatnych była obecność w sądzie pańskich urzędników i innych przedstawicieli władz dominialnych. Okazuje się bowiem, że i w sądach miast królewskich od czasu do czasu pojawiali się przedstawiciele władz starościńskich $^{46}$. Ponadto, w przypadkach sprowadzania sądu miejskiego na wieś $\mathrm{w}$ rozpoznaniu sprawy czasami uczestniczyli również przedstawiciele

42 J. Wijaczka, Proces o czary we wsi Młotkowie w 1692 roku. Przyczynek do polowania na czarownice w Rzeczypospolitej w XVII wieku, „Odrodzenie i Reformacja w Polsce" 48, 2004, s. 167, 170.

${ }^{43}$ Inne szczególne cechy postępowania, jak np. tworzenie sądów złożonych (radziecko-ławniczych), ograniczanie możliwości obrony oskarżonego, spora dowolność w sposobie rozpoznawania poszczególnych spraw itp., to raczej cechy wymiaru sprawiedliwości w małych miejscowościach i nie sposób przypisywać je wyłącznie miastom prywatnym.

${ }^{44}$ Archiv Jugo-Zapadnoj Rossji..., t. 5, cz. 1, s. 260 (nr CIII).

${ }^{45}$ Szerzej na ten temat zob. M. Mikołajczyk, Proces kryminalny $w$ miastach..., s. $186-190$.

${ }^{46}$ Tamże, s. 47-48; zob. też W. Ćwik, Uprawnienia administracyjno-sqdowe starostów $w$ miastach Lubelszczyzny $w$ drugiej połowie XVIII wieku, CPH, t. 15, 1963, z. 1, s. 158 , por. też s. $161-162$. 
tamtejszych władz dominialnych ${ }^{47}$. Odpowiednikiem sądów dominialnych, do których zanoszono apelacje w miastach prywatnych, w przypadku miast królewskich byli w pewnym stopniu starostowie - choć nie wiemy, jak często trafiały do nich odwołania w sprawach kryminalnych ${ }^{48}$. Znamy też sprawy, w których wyrok sądu miejskiego zatwierdzał lub łagodził nie pan miasta, lecz właściciel wsi, z której pochodził oskarżony $^{49}$. Dodajmy wreszcie, że w głośnej sprawie weneckich artylerzystów oskarżonych o nieumyślne spowodowanie śmierci kilku osób, toczącej się w 1683 i 1684 r. w Krakowie, odnotowano nie tylko suplikę zaniesiona przez oskarżonych do bawiacego akurat w stolicy Jana III, ale i królewska decyzję, by sprawa, wszczęta jako kryminalna, rozpatrywana była od tej chwili civiliter, co m.in. nie pozwalało na orzeczenie zbyt surowych kar ${ }^{50}$. Jak się okazuje, nawet doraźne interwencje $\mathrm{w}$ tok postępowania nie musiały być charakterystyczne wyłącznie dla miast prywatnych. Dlatego też stwierdzić należy, że choć wyczuwamy pewną odrębność postępowania karnego w miastach prywatnych i da się zauważyć pewne szczególne jego cechy, to jednak trudno byłoby mówić o wyraźnych, ostrych granicach oddzielających to postępowanie od procedur stosowanych $\mathrm{w}$ innych, zwłaszcza niewielkich miejscowościach (królewskich).

Czy w takiej sytuacji jesteśmy zatem w stanie wyróżnić cechy wspólne, charakteryzujące proces w miastach szlacheckich i duchownych. Interwencje pańskie dostrzegamy we wszystkich miastach prywatnych, których praktykę sądową zdołaliśmy w mniejszym lub większym stopniu poznać. Jednak sposoby ingerowania w miejski wymiar sprawiedliwości, a zwłaszcza częstotliwość wykorzystywania poszczególnych

${ }^{47}$ Zob. M. Mikołajczyk, Proces kryminalny w miastach..., s. 47. Na przykład w sprawie o czary rozpatrywanej w 1674 r. w Kalinie Wielkiej przez sąd sprowadzony ze Słomnik uczestniczył miejscowy podstarości Stanisław Górski; Materiały do etnografii ludu polskiego z okolic Kielc, wyd. W. Siarkowski, do druku przyg. L. Michalska-Bracha, K. Bracha, Kielce 2000, cz. 2, s. 85 (nr II).

${ }_{48}$ Por. M. Mikołajczyk, Proces kryminalny $w$ miastach..., s. 512-513.

${ }^{49} \mathrm{~W} 1733$ r. w aktach oświęcimskich zapisano, że po skazaniu na powieszenie złodzieja „z wyraźnego ordynansu” jego pani, kasztelanowej inowłodzkiej, „darowany jest życiem tenże obwiniony” pod warunkiem złożenia przysięgi, że „więcej kraść nie będzie i z poddaństwa uchodzić nie będzie"; AP w Krakowie, Oddział na Wawelu, Akta depozytowe, sygn. 327 (Oświęcim), plik VIII, cz. 2, k. 18; szerzej na ten temat zob. M. Mikołajczyk, Proces kryminalny w miastach..., s. 521, 526.

${ }^{50}$ M. Mikołajczyk, Sadowy epilog krakowskich obchodów zwycięstwa pod Wiedniem $w 1683$ roku, w: Świat, Europa, mała ojczyzna. Studia ofiarowane profesorowi Stanistawowi Grodziskiemu w 80-lecie urodzin, red. M. Małecki, Bielsko-Biała 2009, s. 275-276. 
środków były bardzo różne. Co więcej, zapewne tylko niektóre rodzaje interwencji (np. decyzje o nadaniu sprawie biegu, akceptacja wyroku) miały wyraźne umocowanie $\mathrm{w}$ prawie zwyczajowym lub stanowionym przez pana, inne wydają się być przejawem woli właściciela bądź jego urzędników wyrażanej ad hoc, w razie zaistnienia potrzeby. Wydaje się zatem, że - póki co - należałoby poprzestać na skromnym wniosku, iż odmienności procesowe występowały, jednak w postaci na tyle zróżnicowanej, że jeżeli mielibyśmy mówić o specyficznym trybie postępowania, to raczej na poziomie konkretnego miasta, ale nie w skali całego kraju czy nawet regionu.

Oczywiście, można sobie wyobrazić dalsze badania, których celem byłoby odnalezienie cech wspólnych, charakterystycznych dla postępowania sądowego (w tym wypadku w sprawach kryminalnych) w miastach prywatnych. Aby dokonać uogólnień, konieczne byłoby zbadanie ustawodawstwa dla większej grupy miast prywatnych i skonfrontowania go z praktyka, co wobec nie najlepszego stopnia zachowania akt spraw kryminalnych nie wydaje się zadaniem łatwym. Ponadto należałoby prawdopodobnie uwzględnić szereg czynników, niekiedy trudno uchwytnych - takich jak sposób zarządzania dobrami, wielkość miasta i związane z tym „przygotowanie zawodowe” sędziów, ich znajomość prawa, stopień zaufania pana do „swych” mieszczan, poczucie obowiązku po stronie właściciela i jego pełnomocników. Nie bez znaczenia może być również rodzaj przestępczości dominującej w danej okolicy (np. zbójnictwo), natężenie tych niekorzystnych zjawisk. Być może warto by zwrócić uwagę, na ile interweniujacy w wymiar sprawiedliwości właściciel miasta występował jako zwierzchnik sądów miejskich, a na ile jako pan sądzonych poddanych, wobec których miał prawo łaski.

Efekty takich badań mogą być jednak bardzo skromne w stosunku do włożonego w nie trudu. Bardzo prawdopodobne wydaje się, że o wiele większy wpływ na sposób procedowania w sprawach karnych miała wielkość miasta, wiedza prawnicza sędziów niż to, czyją owo miasto było własnością. Jest zresztą możliwe, że odpowiedź na postawione pytania jest stosunkowo prosta. Pan miasta, postrzegany jako absolutny władca swych poddanych ${ }^{51}$, nazywany najwyższym sędzią ${ }^{52}$, miał praktycznie nieograniczone możliwości ingerowania w miejski wymiar sprawiedliwości. Mógł to czynić osobiście albo za pośrednictwem swych

${ }^{51} \mathrm{~W} 1713$ r. stwierdzono, że burmistrz Opalenicy, który wypowiedział jakieś „słowa nieuczciwe” pod adresem właściciela miasta, „popełnił crimen laesae Maiestatis"; AGAD, BBaw., sygn. 252 (Grodzisk Wielkopolski), k. 31v-32).

${ }^{52}$ W wielkopolskim Grodzisku pan miasta określany był jako „supremus Arbiter et Iudex"; tamże, k. 40v (1714 r.), 43v (1714 r.). 
podwładnych, mógł ustalać pewne reguły postępowania, które mu ułatwiały kontrolę nad sądownictwem, ale równie dobrze mógł poprzestać na doraźnych interwencjach, a zapewne mógł z tego prawa również zrezygnować - tak jak to ponoć uczynił właściciel Chrzanowa w $1781 \mathrm{r}^{53}$ (inna rzecz, że był to prawdopodobnie powiew nowych czasów i wpływ idei oświecenia).

Czy jednak oznaczało to całkowita dowolność poczynań? ${ }^{54} \mathrm{I}$ w tym wypadku wskazana byłaby - jak sądzę - ostrożność. Zauważmy, że choć intensywność tych działań była różna, to jednak - nawet wtedy, gdy przybierały one formę regularnego kontrolowania miejskich sądów - widać w nich pewien umiar. Odnosimy wrażenie, że właściciele miast i ich urzędnicy generalnie respektowali zasady funkcjonowania sądownictwa miejskiego i normy prawa magdeburskiego, że nie wywracali oni swymi interwencjami istniejącego porządku prawnego - przykład pana Żywca, który zamienił orzeczone kary śmierci na niemal równie okrutne, a sprzeczne z prawem kary mutylacyjne ${ }^{55}$, to raczej wyjątek potwierdzajacy regułę.

Zbyt głębokie ingerencje $\mathrm{w}$ miejski wymiar sprawiedliwości byłyby chyba zreszta sprzeczne $\mathrm{z}$ interesem właściciela, podważałyby w jakiś sposób szczególny status miejscowości, o który zabiegał on sam albo jego prawni poprzednicy, status wyróżniający ją spośród innych posiadłości szlacheckich, klasztornych, biskupich. Zmiany wprowadzano wtedy, gdy wymagał tego zdrowy rozsądek, poczucie sprawiedliwości, zasady słuszności. Zauważmy zreszta, że tak samo postępowali sami sędziowie - zwłaszcza w większych miastach - gdy zdawali sobie sprawę, że obowiązujące prawo okazuje się w konkretnym przypadku zbyt surowe, niesprawiedliwe i odbiera przestępcy szansę na poprawę ${ }^{56}$.

${ }^{53}$ Józef Salezy Ossoliński uznał, że prawo to niesłusznie sobie przypisali pańscy urzędnicy; J. Stoksik, Wtaściciele Chrzanowa od poczatku XVII do 1. pot. XIX wieku, w: Chrzanów. Studia z dziejów miasta i regionu do roku 1939, Chrzanów 1998, s. 141; taż, Chrzanów i jego mieszkańcy od poczatku XVII do poczatku XIX wieku, w: tamże, s. 181.

${ }^{54}$ Swego czasu J. Mazurkiewicz, J. Reder i J. Markiewicz tak postrzegali położenie samorządu miejskiego wobec panów, „którzy mogli w sposób omal dowolny z nim postępować”; ciż, dz. cyt., s. 120.

${ }^{55}$ Owe „innowacje” zostały źle przyjęte przez opinię publiczna. Andrzej Komoniecki stwierdził, że egzekucja była w tym przypadku „niezwyczajna i nad prawo uczyniona”, a ludzie obserwujący odcinanie złoczyńcom rąk i nóg oraz wypalanie im na czołach szubienic „na to patrzać nie mogli”; tenże, dz. cyt., s. 459-460 (1714 r.), zob. też s. 300 (1705 r.).

${ }_{56}$ Por. M. Mikołajczyk, Przestepstwo $i$ kara $w$ prawie miast Polski południowej XVI-XVIII wieku, Katowice 1998, s. 170, 189-192; tenże, Proces kryminalny w miastach..., s. 476-477. 


\section{Bibliografia}

\section{Źródta}

Rękopisy

AGAD, Biblioteka Baworowskich, sygn. 252 (Grodzisk Wielkopolski).

AP w Krakowie, Inwentarz tymczasowy, sygn. 229c (Nowa Góra), 229b (Nowa Góra), 229g (Nowa Góra), 229h (Nowa Góra).

AP w Krakowie, Oddział na Wawelu, Akta depozytowe, sygn. 327 (Oświęcim). BJ, sygn. 86 (Miechów), 122 (Nowa Góra).

Muzeum Okręgowe w Tarnowie, sygn. MT-H 505 (Tarnów).

Wydawnictwa źródłowe

Acta maleficorum Wisniciae (1629-1665). Księga złoczyńców squdu kryminalnego w Wiśniczu (1629-1665), wyd. W. Uruszczak, współpr. I. Dwornicka, Kraków [2004].

Acta maleficorum Wisniciae (1665-1785). Księga czarna złoczyńców sqdu kryminalnego w Wiśniczu (1665-1785), oprac. i wyd. W. Uruszczak, współpr. B. Migda, A. Karabowicz, A. Uruszczak, Kraków 2010.

Archiv Jugo-Zapadnoj Rossji, t. 5, cz. 1, Kijew 1869.

Komoniecki A., Chronografia albo Dziejopis żywiecki, wyd. S. Grodziski, I. Dwornicka, Żywiec 1987.

Kopiariusz przywilejów miasta Łańcuta, wyd. M. Nitkiewicz, Łańcut 1986.

Materiały do dziejów miasta Żywca od XV do XVIII wieku, wyd. F. Lenczowski, Kraków 1957.

Materiaty do etnografii ludu polskiego z okolic Kielc, wyd. W. Siarkowski, do druku przyg. L. Michalska-Bracha, K. Bracha, Kielce 2000.

Przywilej miastu Łobżenice nadany przez Jana Korzboka Łackiego, Poznań 1883.

Uchwała albo porzadek postanowienia artykutów, wedle których opisania mieszczanie $i$ obywatele miasta Liska sprawować się $i$ obchodzić maja [1602 r.], w: A. Fastnacht, Dzieje Leska do 1772 roku, Rzeszów 1988.

Wyrobisz A., Poczatki miasta Janowca nad Wista. Dokumenty z lat 1537, 1566, 1580, [Janowiec nad Wisła] 1999.

\section{Opracowania}

Bogucka M., Samsonowicz H., Dzieje miast i mieszczaństwa w Polsce przedrozbiorowej, Wrocław 1986.

Ćwik W., Uprawnienia administracyjno-sqdowe starostów w miastach Lubelszczyzny w drugiej połowie XVIII wieku, CPH, t. 15, 1963, z. 1.

Fijałek J., Koliński J., Dzieje miasta $w$ XVII i XVIII wieku, w: Dzieje Pabianic, red. G. Missalowa, Łódź 1968.

Janusz G., Miasto Janowiec nad Wisła. Ustrój władz miejskich i stosunki spoteczno-ekonomiczne w świetle przywilejów, Janowiec 1999. 
Kaźmierczyk A., Żydzi $w$ dobrach prywatnych $w$ świetle sqdowniczej $i$ administracyjnej praktyki dóbr magnackich $w$ wiekach XVI-XVIII, Kraków 2002.

Kulejewska-Topolska Z., Nowe lokacje miejskie w Wielkopolsce od XVI do końca XVIII wieku. Studium historyczno-prawne, Poznań 1964.

Leśniak F., Miasto $w$ latach 1565-1772, w: Limanowa. Dzieje miasta, t. 1: 1565-1945, red. F. Kiryk, Kraków 1999.

Maciejewski T., Narzędzia tortur, sqdów bożych i prób czarownic, Koszalin 1997.

Mazek D., Ku ozdobie i profitowi. Prawodawstwo miast prywatnych Wielkopolski 1660-1764, Warszawa 2003.

Mazurkiewicz J., Jurydyki lubelskie, Wrocław 1956.

Mazurkiewicz J., O niektórych problemach prawno-ustrojowych miast prywatnych $w$ dawnej Polsce, „Annales Universitatis Mariae Curie-Skłodowska” 1964, Sectio G, t. 11, z. 4.

Mazurkiewicz J., Reder J., Markiewicz J., Miasta prywatne powiatu lubelskiego a ich dziedzice $w$ XIX w. (Do ukazów uwtaszczeniowych), „Annales Universitatis Mariae Curie-Skłodowska” 1954, Sectio G, t. 1, z. 3.

Mikołajczyk M., Nadzór właścicieli wielkopolskiego Grodziska nad miejskim sqdownictwem $w$ sprawach kryminalnych $w$ I połowie XVIII wieku, $\mathrm{w}$ : Historia testis temporum, lux veritatis, vita memoriae, nuntia vetustatis. Ksiega jubileuszowa dedykowana profesorowi Włodzimierzowi Kaczorowskiemu, red. E. Kozerska, M. Maciejewski, P. Stec, Opole 2015.

Mikołajczyk M., O zatwierdzaniu wyroków sqdu miejskiego w Nowej Górze w XVIII wieku, w: Studia z dziejów państwa i prawa polskiego, t. 5, red. J. Matuszewski, W. Uruszczak, Łódź-Kraków 2000.

Mikołajczyk M., Proces kryminalny w miastach Małopolski XVI-XVIII wieku, Katowice 2013.

Mikołajczyk M., Proces kryminalny w Nowej Górze XVI-XVIII wieku, w: Miscellanea Iuridica, t. 7: Między I a III Rzeczapospolita. Ksztattowanie europejskiej kultury prawnej. Prace ofiarowane prof. zw. dr. hab. Adamowi Lityńskiemu w czterdziestolecie pracy naukowej, red. M. Mikołajczyk, A. Drogoń, Tychy 2005.

Mikołajczyk M., Przestepstwo i kara $w$ prawie miast Polski południowej XVI-XVIII wieku, Katowice 1998.

Mikołajczyk M., Sadowy epilog krakowskich obchodów zwycięstwa pod Wiedniem w 1683 roku, w: Świat, Europa, mała ojczyzna. Studia ofiarowane profesorowi Stanisławowi Grodziskiemu w 80-lecie urodzin, red. M. Małecki, Bielsko-Biała 2009.

Opas T., Zagadnienie apelacji mieszczan miast prywatnych $w$ świetle polityki gospodarczo-społecznej dziedziców od XVI do XVIII wieku, „Annales Universitatis Mariae Curie-Skłodowska” 1973, Sectio G, t. 20, z. 2.

Pęckowski J., Dzieje miasta Rzeszowa do końca XVIII wieku, Rzeszów 1913 (reprint: Krosno 2002).

Sarna W., Opis powiatu jasielskiego, Jasło 1908 (reprint: Jasło 2003). 
Stoksik J., Chrzanów i jego mieszkańcy od poczqtku XVII do poczqtku XIX wieku, w: Chrzanów. Studia z dziejów miasta i regionu do roku 1939, Chrzanów 1998.

Stoksik J., Wtaściciele Chrzanowa od poczatku XVII do 1. pot. XIX wieku, w: Chrzanów. Studia z dziejów miasta i regionu do roku 1939, Chrzanów 1998.

Sztachelska-Kokoczka A., Oleksicki A., Biatystok w czasach Branickich (lata 1708-95), w: Historia Białegostoku, red. A.C. Dobroński, Białystok 2012.

Trojan M.T., Dzieje sqdownictwa wielkiego Opatowa, Sandomierz 1938.

Wijaczka J., Proces o czary we wsi Mtotkowie w 1692 roku. Przyczynek do polowania na czarownice $w$ Rzeczypospolitej $w$ XVII wieku, „Odrodzenie i Reformacja w Polsce" 48, 2004.

Witkowski W., Ordynacje pańskie dla miast prywatnych w Polsce XVII i XVIII stulecia, w: Z historii państwa, prawa, miast i Polonii. Prace ofiarowane profesorowi Władysławowi Ćwikowi w czterdziestolecie jego pracy twórczej, red. J. Ciagwa, T. Opas, Rzeszów 1998.

Zajac A., Управління та самоврядування в містах Правобережної України у XVI - першій половині XVII cm. за данили локаційних привілеїв та документів, w: Urzędy państwowe, organy samorzadowe i kościelne oraz ich kancelarie na polsko-ruskim pograniczu kulturowym i etnicznym $w$ okresie od XV do XIX wieku. Materiaty polsko-ukrainskiej konferencji naukowej w Okunince koło Wtodawy, 10-12 września 2007 roku, red. H. Gmiterek, J. Łosowski, Kraków 2010.

Zajęcki M., Instrumenty prawne ochrony przeciwpożarowej $w$ miastach Polski przedrozbiorowej, Poznań 2014.

Marian Mikołajczyk

Judicial system in private towns in Poland in the $16^{\text {th }}-18^{\text {th }}$ century. The issue of differences in criminal proceedings (Summary)

Private towns, owned by the nobility or the Church, constituted a significant part of all towns in Poland. They varied quite significantly from royal towns. Their disparate nature manifested itself primarily in various ways of interference of the owners and their appointed representatives with the municipal administration matters. The judicial system was not free from these interferences as well - it is known that the owners would often affect the course of criminal proceedings. Research shows that the differences of criminal proceedings in private towns as compared to royal towns were practically limited solely to this - often very extensive - involvement of owners in the legal process. Proceedings were often started at the request of the owner, whose representatives often kept a close watch throughout their course; there are also many known cases of the rulings of municipal courts requiring confirmation of the owner. 
It needs to be asked, however, whether these disparities were important and widespread enough to be regarded as forming a legal process specific for private towns. The ways in which the owners interfered with the municipal judicial system varied and had marginal connection to customary law. They were most often introduced ad hoc and depended on the activity or passivity of an individual owner. It also needs to be noted that certain (often very similar) ways of limiting the independence of the judiciary in giving rulings in criminal cases could be observed in smaller royal towns. It would therefore seem that there are no strong bases to claim that a separate manner of criminal proceedings existed in private towns.

Marian Mikołajczyk - (ur. 1959), prof. dr hab., kierownik Katedry Historii Prawa na Wydziale Prawa i Administracji Uniwersytetu Ślaskiego w Katowicach. Specjalizuje się w historii prawa sądowego przedrozbiorowej Polski, interesuje się także dziejami przestępczości. W ostatnich latach zajmuje się przede wszystkim dziejami prawa miejskiego. Autor około 100 publikacji, w tym czterech monografii, m.in.: Przestepstwo $i$ kara $w$ prawie miast Polski potudniowej XVI-XVIII wieku, Katowice 1998; Proces kryminalny w miastach Małopolski XVI-XVIII wieku, Katowice 2013. E-mail: mikolajczyk59@interia.pl. 